peritoneum. In two cases a circumscribed cavity was described as communicating with the perforation. There is yet one more point to be considered.

The associnted lesions.--In 46 cases there was no lesion observed other than what may be due to typhoid fever itself. In 27 cases the following, in addition to the typhoid lesions, were also present: the pericardium was adherent in 1 case there was valvular disease of the heart in 4 cases, mitral stenosis being present in 2 cases, mitral regurgitation in 1 case and mitral regurgitation with aortic disease in the other case; the kidneys were diseased in 5 cases, being described as "granular" in 3, "fatty" in 1 and "suppurative nephritis" in the other. Pneumonia was recorded as being present in 5 cases and pleurisy in 3 cases. Pus was found in the mesenteric glands in 2 instances, bxmorrbage into the stomach through an ulcer in 1 case and acute abscesses in each rectus abdominis in 1 case: an ulcer in the larynx was observed in 1 case and in another there had been a recent abortion. These facts must be left to speak for themselves even at the expense of my being considered "a dull collector of facts." On a future occasion I hope to make these important, if dull, kinetics potential when I come to write on the treatment of perforation.

Wimpolesstreet, $W$.

\section{FIVE CASES OF}

ALBUMINURIA GRAVIDARUM WITH ECLAMPSIA, FOR WHICH VENESECTION WAS PERFORMED IN TIVO; RECOVERY OF ALL.

BY ROBERT KIRK, M.D. EDIN, F.F.P. \& S. GLAS., PHYSICIAN TO THE DISPENSARY FOR DISEASES OP WOMEN, GLASGOW WESTERN INFIRMARY.

THE following cases furnish an additional illustration of what has been so often the subject of remark -viz, how we may sometimes have a series of the same class of cases in close succession.

CASE 1.-A married woman, in the eighth month of her first pregnancy, was seized with a violent headache at $5 \mathrm{~A} . \mathbf{M}$. on Dec. 9th last, and general convulsions commenced two hours afterwards. These went on till I saw her twelve hours afterwards and she was quite unconscious between the attacks. She had a violent fit on my arrival, immediately after which I bled her to sixteen ounces. Six ounces of pale urine were drawn off by catheter, which was found to be albuminous to one-third of the column of liquid. She was not in labour. There was no anasarca, and the ankles did not pit on pressure. After the bleeding the fits became shorter, lasting one minute instead of three as before, but they continued every half hour till $5 \mathrm{~A}$. M. next morning. At 7 A.M. expulsive efforts commenced, and when I saw her at 11 A.M. labour was so far advanced that I delivered with forceps; the child was stillborn (perhaps dead some hours). The patient made a good recovery; the first urine after delivery (twenty-six hours) was drawn off by catheter (thirty-two ounces), and contained the same amount of albumen as before.

CASE 2.-A married woman, in the ninth month of her first pregnancy, was seized with convulsions on April 2nd last, after headache and romiting. She had come from Belfast on the preceding night. I first saw her after three violent attacks, and she had a severe seizure in my presence, after which I bled her to twenty-four ounces (she was stout and florid). There was no anasarca or pitting of the ankles; some urine drawn off by catheter was albuminous to half the column. Labour was progressing, the os being dilated to the size of a florin. Four convulsions ensued within the next hour, but they then ceased and I effected delivery by the forceps, six hours after I had first seen her. The child was alive and well. Singularly enough, the convulsions recurred with the same severity as before six hours after delivery, but finally ceased after four attacks within an hour. Previously to these she had had a few doses of bromide and chloral. She made an uninterrupted recovery.

The blood serum in both these cases was examined for uric acid, but none was found.

The three cases in which there were no convulsions were also all primiparæ. In all three there was anasarca. In one case I was first summoned when the patient was in actual labour, and I delivered her with the forceps under a profound dose of chlorolorm, which I need hardly saty she bore perfectly well. The anasarca was not great in this case. The second patient came under observation in the sixth month of pregnancy, with swollen logs and albuminuria. She was treated for a fortnight, during which the anasarca was a good deal reduced. Premature labour then came on and the child was born alive and lived four days. The thire case was that of a slim, diminutive woman, twenty-soven years of age, who was first seen two wecks before labour canie on, when she said that she was in the ninth month of pregnancy. There was great anasarca, extending to the loins and in front to the epigastrium. No foctal movements had bcen felt for some time past, and on auscultation neither the fretal heart nor the placental souflle could be heard. The urine was albuminous to a quarter of the column. The treatment failed either to diminish the anasarca or the albumen in the urine. When labour came on, fearing the rapid absorption of the serous effusion, which $I$ am inclined to regard as a possible source of danger after delivery, I made an incision into each ankle, from which the serum drained away freely. When the child was born the craniat bones were very loose, and there was no doubt that it had been dead for a considerable time. The mother made a good recovery, but the urine still contained, some months after delivery, a considerable quantity of albumen. In all the cases the albuminous urine was of the frothless variety, so common in acute nephritis.

Partick, Glasgow.

\section{BRONCHIAL CASTS IN CONNEXION WITH MITRAL REGURGITATION.}

\section{BY SIDNEY C. LAWRENCE, L.R.C.P. LOND., M.R.C.S.}

ON June 4th, 1892, I first saw the patient, a boy of nine years of age. His previous history was that he had had good health till November, 1891, when he had an attack of "inflammation of the heart." Since that illness be had felt weak and not equal to his school work, but he had not been troubled with shortness of breath or cough. His mother enjoys good health and he had lost a sister in her infancy from scarlet fever. His father, aged fifty, has had several attacks of rheumatic fever and "has a weak heart." The boy wassmall for his age, poorly nourished (though not emaciated) and with a harsh, dry shin. Auscultation revealed a loud regurgitant murmur at the heart's apex, but no abnormal sounds in the lungs. The pulse was about 80 , small and soft, but regular. The apex beat was at the fifth rib in the nipple line. I prescribed cod-liver oil emulsion and a mixture of citrate of iron with nux romica. I next saw him on August 4th, a month intervening, when I was hastily summoned because he was spitting up "queer things like little trees." I was shown one his mother had put in a saucer of water. It was similar to the one depicted in the engraving on next page, but rather smaller, quite white and circular in section. He had no fresh symptoms to complain of, no rise of temperature and no dyspncea. The mitral bruit was as before, but just below the angle of the left scapula I could detect a patch of consolidation the size of a crown piece. On Jan. 1st, 1893, I was again in attendance. I was told that since August till the last week or so he had been in his usual health, coughing up the casts at irregular intervals. He would cough one or two up daily for a few days or a fortnight and then cease for a month or so. The casts were still quite white and occisionally had a streak of bright blood on them which washed off instantly in water. Sometimes they were not perfectly round in section, but flattened as if the cast had not completely occluded the bronchus. Before expectorating a cast he felt a "tickling " cough for some hours. On New Year's Day I found his mitral regurgitation worse, there wis some ascites, and he had a left inguinal hernia. The liver dulness, if increased at all, was only slightly so and that at the upper border, but there was no tenderness over the liver. I conld find no trace of the consolidated patch that had existed below the angle of the left scapula in Angust, but I discovered a fresh one of the same size at about the second interspace below the right apex. There was no dyspnoca or pyrexia. I was told that for a week or two past the cough had been more intense hence, I presume, the hernia. I ordered him to keep his bed and prescribed strophanthus and nux vomica. He soon got better. The fluid in the abdomen disappeared and his pulse 
improved After a week's attendance I allowed three weeks to elapse before again visiting him. Then I found that he was complaining of greater weakness, loss of appetite and marked loss of flesh. The consolidation was of yreater extent and involved the whole of the apex. From that time the area of consolidation increased till Feb. 20th, when the whole of the upper right lobe appeared solid. Then, and not before, his respiration increased to 30 and then to 35 a minute and his temperature that morning was $1035^{\circ} \mathrm{F}$. Now he presented the appearance of a typical acute pneumonia, though his sputum was not "rusty" but copious, and his cough was troublesome. The expectoration consisted partly of bronchitic froth and partly of shreds of dirty-white material, as of broken-up casts ; it was not offensive in odour. The dyspnoea continued and the temperature kept up till the $24 \mathrm{th}$, then the temperature fell to normal or a little below; but his respirations numbered between 20 and 25 a minute. The boy continued getting weaker and thinner and was unable to leave his bed. On March 6th ascites reappeared. The expectoration was still copious and of the same character. After the febrile attack he never expectorated any whole casts. The left lung and lower lobes of the right remained free from complication till March 11th, two days

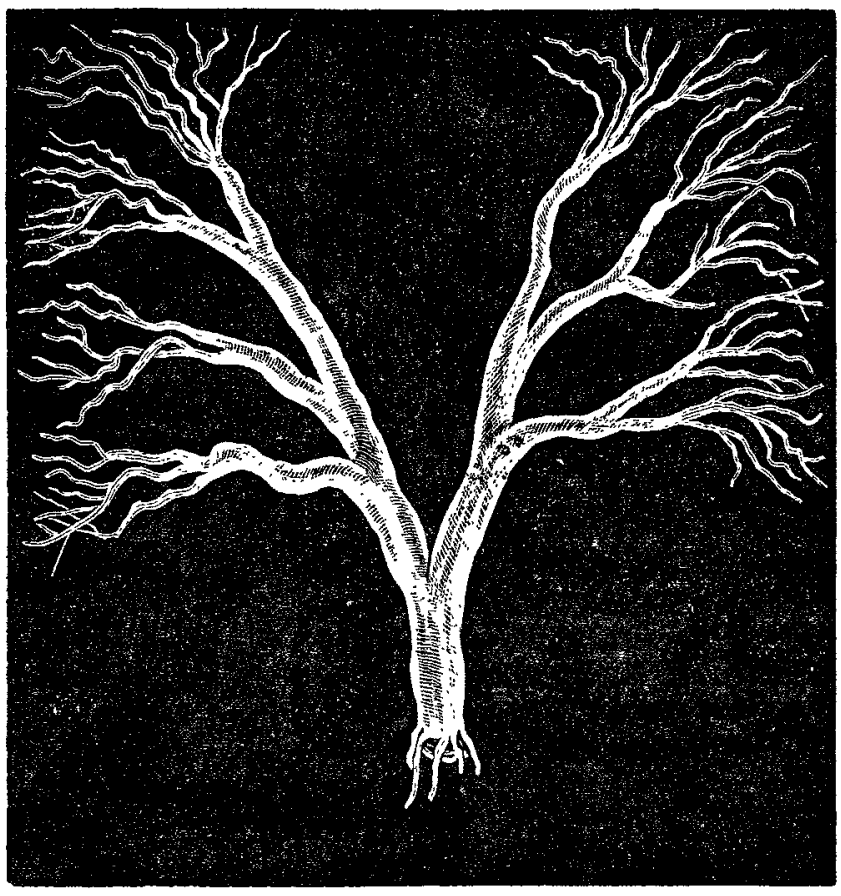

before his death, when signs of cdema and congestion of the lungs became general. His pulse was now very quick and irregular and his urine scanty, being loaded with urates and presenting a cloud of albumen when tested. On March 13th, at half-past one in the morning, he passed quietly away. No post-mortem examination, unfortunately, could be obtained.

Remarks. - The expectoration of bronchial casts is so rare a condition that I consider this case worthy of record I was much interested to read in an article by Dr. $R$. W. Richards in THE LANCET of May 20th of this year of the occurrence of bronchial casts of a different character and under other cir cumstances. As he says, the text-books contain very little ( $n$ the subject; Bristowe figures two casts (natural size), but not so large as some expectorated by my patient. My case is singular in the little local trouble experienced and in the absence of constitutional effects till towards the end, when the exudation apparently filled up the bronchi of the whole upper right lobe. Then the casts seemed to adhere to the tubes and only came away in shreds and not whole. I am at a loss to rightly estimate the connexion between the cardiac trouble and the bronchial casts. Were the latter simply formed by excess of blood-pressure in the lobules squeezing out the fibrinous material in a mechanical manner into the bronchi? The casts would seem not to be due to any inflammatory process, for the boy was expectorating them from Aug. $4 \mathrm{th}$ till Feb. 20th without any dyspnœen or rise of temperature. The absence of the former symptom, I consider, was due to the small area of lung involved at any one time. I am fortunately able to publish a drawing of one of the largest casts. It is the natural size and well depicted by ny friend, Mr. Harry Evans. The casts were exhibited and the history of the case related to the Bournemouth Medical Society on Feb. 17:h, 1893.

Bounremouth.

\section{Climital 繁otes:}

MEDICAL, SURGICAL, OBSTETRICAL AND THERAPEUTICAL.

\section{NATURAL OBSTETRICS. \\ BY F. Enson, M.R.C.S. \&c.}

Johx Stuart MiLL writes: "In the clumsy provision which she has made for that perpetual renewal of animal life rendered necessary by the prompt termination she puts to it in every individual instance no human being ever comes into the world but another human being is literally stretchet on the rack for hours or days." I In order to show that to this rule there are some happy exceptions I think it mar interest the readers of THE LANCET to peruse the following Some time ago I was in attendance on a young woman gentle birth and of as fine a physique as one would see in day's march. It was her first child, and although quite normal the labour was tedious. In the intervals of th "clumsy"' process to which J. S. Mill alludes I (as I daresa many of your readers have done) retired to the smoking-roon and passed the time in friendly chat with the young husbanc a fine, intelligent young colonist, who had lived in Zululan knew the natives well and could speak the language fluentir I inquired of him how the Kaffir women managed under similar circumstances. He replied that "a young woma will remain with the elders at her first childbirth in the bet but in subsequent labours she always goes away into the bush alone and manages her trouble." A short time pre viously he was riding home, with gun on shoulder, when Kaffir man stepped out of the bush and, saluting him with the grace and good manners innate in the uncivilised karos bearing native, said, "Inkosi, give me some gunpowder, "What do you want it for?" the husband of my patier asked. "Zala umtwana," was the answer, which bein interpreted means, "My wife has laid a child." He gase him a charge of powder from a cartridge, three and a hall drachms, and rode on to the homestead. In abont to hours the woman made her appearance with a fine male child; she had walked seven miles to his house and was seen by her master subsequently, being quite well an hearty. The woman was about thirty years of age and it mi her second child She must have been taken in labour whils on a journey, and the delay in the afterbirth was the caused the request for the gunpowder. I think the natives must han learned this remedy to induce uterine contraction from Dutch midwife, but I cannot say. I suppose the nitre is th essential ingredient. Another case was that of a Katit woman aged about forty, who was at least a mile from hom and carried on her head a bundle of firewood big enough for a donkey-load to the house. Passing the kitchen she said th her daughter, "I feel pains, I must go to the bush, I will leave the sticks here." She was away for about three hous having taken the new arrival to her hut, she returned to th kitchen and carried off the firewood. I am quite sure that the illustrious logician when he penned the lines I har quoted never officiated at a Kaffir accouchement. Kaffi men and women in their natural state are a very fine rax indeed; it is only when they settle in towns that the degenerate and die prematurely. Drink, phthisis an syphilis do their deadly work. The black coat is a tuniod Nessus to them and they perish in its unnatural folds. Pli. bushmen, the real Hottentots, the bastard yellow people are fast disappearing; but the thoroughbred Kaflir, ondy the protecting reign of British law, is increasing rapidy and it will need all the wisdom of the Colonial Office to turn the tide of native expansion into the paths of peace or the tins: will come when the whites in South Africa will either the pushed off the land or be absorbed into the more endurin? native race.

Port Elizabeth, South Africa.

\section{VARICOSE VEINS IN BOTH ARMS.}

\section{By A. S. Dutton, M.R C.S.Eng., L.R.C.P.Lond.}

AN interesting case of varicose veins in both arms recently come under my notice, and as I have never sert similar case before and do not remember to have seen 